\section{Effects of Slope and Underlay on Surface Runoff of Irrigation from Woven Polypropylene Groundcloth}

\author{
Jeff Million ${ }^{1}$, Tom Yeager ${ }^{1,3}$, Henry Bryant ${ }^{1}$, Claudia Larsen ${ }^{1}$, \\ Joe Shook ${ }^{1}$, and Joseph Albano ${ }^{2}$
}

ADDITIONAL INDEX wORDs. drainage, geotextile, irrigation rate, leachate, overhead irrigation, plastic groundcover, fabric, runoff percentage

\begin{abstract}
SUMMARY. Woven polypropylene groundcloth is used extensively in plant nurseries as a permeable and durable surface for container plant production. To better understand the fate of overhead sprinkler irrigation water, we designed and constructed runoff platforms $\left(2.7 \mathrm{~m}^{2}\right)$ to measure runoff and leachate from single irrigation events as affected by slope and underlay substrates. Groundcloth-covered platforms at slopes of $1.5 \%$ and $11 \%$ were tested with each of five underlay treatments: no underlay, coarse sand, $50 \%$ coarse sand and $50 \%$ no underlay (CS50), gravel, and native sandy soil. We applied $0.9 \mathrm{~cm}$ of irrigation at 1.8 $\mathrm{cm} \cdot \mathrm{h}^{-1}$ and determined runoff and leachate volumes. Runoff percentage [runoff $\times$ $100 \% /($ runoff + leachate $)]$ increased at the $11 \%$ slope for each underlay treatment. Mean $(n=10)$ runoff percentages $(\mathrm{RP})$ for the $1.5 \%$ and $11 \%$ slopes were $0.5 \%$ and $15.7 \%$, respectively, for no underlay, $0.1 \%$ and $1.1 \%$ for coarse sand, $0.1 \%$ and $0.7 \%$ for CS50, $0.7 \%$ and $2.5 \%$ for gravel, and $0.1 \%$ and $3.1 \%$ for native sandy soil. The low RP observed indicate that a high percentage of nutrients and agrichemicals associated with container leachate would move into the underlying substrate or soil rather than directly running off into surface waters.
\end{abstract}

$\mathrm{P}$ olypropylene groundcloth is a semi-permeable, woven geotextile commonly used as a groundcover in container plant nurseries. Groundcloth is placed over native soil or other underlying substrate (underlay) to reduce erosion, prevent weed growth, and provide a durable and clean surface for container plant production. The weave in the groundcloth allows water to penetrate the groundcloth, which promotes infiltration of water into the underlay. Therefore, physical properties of groundcloth and underlay are important in determining the fate of water and associated agrichemicals in a nursery.

The effect of groundcloth and underlay on the amount of surface runoff generated from overhead irrigation has not been quantified. Irrigation water must penetrate both the groundcloth

\footnotetext{
${ }^{1}$ Department of Environmental Horticulture, University of Florida, IFAS, 1545 Fifield Hall, Gainesville, FL 32611-0670.

${ }^{2}$ U.S. Horticultural Research Laboratory, USDA, ARS, Ft. Pierce, FL 34945

This research was supported by the Florida Agricultural Experiment Station and a grant from the Nursery and Floral Research Initiative, USDA, ARS. Approved for publication as Journal Series No. R-10726. The authors thank Bart Schutzman for the platform diagram.

${ }^{3}$ To whom reprint requests should be addressed. E-mail
} address: tyeager@ifas.ufl.edu and the underlay surface for surface runoff not to occur. Permeability of groundcloth is indicated by its permittivity, which is the ability of a geotextile to pass water normal to the geotextile (Carroll, 1987). Although water permeability values for woven polypropylene groundcloth are high, laboratory tests are based upon applying a steady column of water to the material. Actual permeability may vary since irrigation water in the field has little hydraulic pressure and water pressure may be exerted at various angles.

Some important characteristics of soil or underlay that affect runoff from irrigation or rainfall include slope and slope length (Schwab et al., 1971), infiltration rate (Beasely, 1977; Parr and Bertrand, 1960), hydraulic conductivity (Hillel, 1980), hydrological group [Soil Conservation Service (SCS), 1985], and antecedent moisture content (Haith and Andre, 2000). At a site with soils of poor infiltration and/or permeability, fill-materials such as coarse sand or gravel can be used as underlay.

Studies of factors affecting the fate of irrigation water are necessary if we want to better understand and manage nutrient and agrochemical runoff generated by nursery production practices. When used alone, the term runoff implies the surface flow of water. In container nursery research, "runoff" is often used to describe the combined contributions of intercepted water that moves through the container (leachate) plus un-intercepted rainfall or irrigation that falls between containers (Briggs et al., 1998; Cole et al., 1993). While impervious plastic sheeting is often placed underneath the groundcloth to divert leachate and un-intercepted irrigation and rainfall for recycling or controlled disposal (Bilderback, 2001; Briggs et al., 1998), in the absence of such an impervious layer, nursery container runoff actually represents the potential for downward movement into the underlying soil and water resources. In this latter case, there is little information on what fraction of this potential runoff actually runs off the surface of the production area.

The objective of our research was to design, construct, and evaluate a platform structure to determine how woven, polypropylene groundcloth affects the partitioning of irrigation water into leachate and runoff fractions in response to slope and underlay substrates. The influence of containers, substrates, and plants on runoff was not investigated in this study.

\section{Materials and methods}

Platform design CONSIDerATIONS. We designed a runoff platform to collect separately both runoff and leachate from single irrigation events. The structure was designed to support the underlay as well as any additional weight of potted plants placed on top. Another important consideration was to provide non-restrictive drainage conditions in the underlay that ap-

\begin{tabular}{lllc}
\hline $\begin{array}{l}\text { Units } \\
\text { To convert U.S. to SI, } \\
\text { multiply by }\end{array}$ & U.S. unit & SI unit & $\begin{array}{l}\text { To convert SI to U.S., } \\
\text { multiply by }\end{array}$ \\
\hline 0.3048 & $\mathrm{ft}$ & $\mathrm{m}$ & 3.2808 \\
0.0929 & $\mathrm{ft}^{2}$ & $\mathrm{~m}^{2}$ & 10.7639 \\
3.7854 & $\mathrm{gal}$ & $\mathrm{L}$ & 0.2642 \\
2.5400 & inch(es) & $\mathrm{cm}$ & 0.3937 \\
0.0254 & $\mathrm{mil}$ & $\mathrm{mm}$ & 39.3701 \\
305.1517 & $\mathrm{oz} / \mathrm{ft}^{2}$ & $\mathrm{~g} \cdot \mathrm{m}^{-2}$ & 0.0033
\end{tabular}


proximate conditions in the field. This was accomplished in part by using a horizontal stainless steel rod support system, which supported the substrate and allowed water to move vertically through the substrate. Standard-sized, pressure-treated lumber and stainless steel screws were used in platform construction.

Platform construction. A partial diagram of the platform structure is given in Fig. 1. The foundation of the platform was a $4 \times 8$-ft sheet of $3 / 4$ inch-thick plywood placed between four $2 \times 4$-inch $\times 8$-ft-long joists, which were cut at an angle so that the plywood had a downward slope when the upper and lower surfaces of the joists were level. The joists were cut so that the ends had short and tall dimensions of $3 / 4$ and $2-3 / 4$ inches, respectively, and this resulted in the plywood having a $2 \%$ slope. The plywood "sandwich" was supported by three horizontal sections of lumber $4 \times 4$ inches thick $\times 4 \mathrm{ft}$ long. An end-piece 2 inches wide $\times 4$ inches high $\times 4 \mathrm{ft}$ long was attached at the higher end of the plywood sandwich only; the lower end was left open to allow for leachate drainage.

The inner $3 / 4$ inch of the outer joists and the end-piece were routed $1 / 3$ inch deep. The same depth was shaved off the top of the inner two joists. Afterward, we routed $1 / 2$-inchwide grooves to hold $1 / 2$-inch (o.d.) $\times$ 47-inch-long stainless steel rods spaced out horizontally to support four panels of plastic grating $(1 / 3$ inch high $\times 2 \mathrm{ft}$ wide $\times 4 \mathrm{ft}$ long) used as light diffusers for ceiling lighting (Fig. 2). We placed pond liner (45-mil EBDM PondGard; Firestone Building Products, Carmel, Ind.) over the platform before installing the steel rods and plastic grating. The liner was adjusted to form troughs between the joists to channel drainage water toward the lower end of the plywood base. The liner was cut so that an extra 2 -ft tail extended beyond the lower end of the plywood base to channel the drainage water into a collection vessel. Once the rods and panels were installed, the surface of assembly "A" was flat and even (Fig. 2 ). Assembly "A" was placed on six standard cement blocks and leveled with wooden shims.

Platform slope was achieved during the construction of Framework " $\mathrm{B}$ " (Fig. 1). For this study we chose $1.5 \%$ or $11 \%$ slopes, which represent the range of slopes likely to exist in nursery pro-

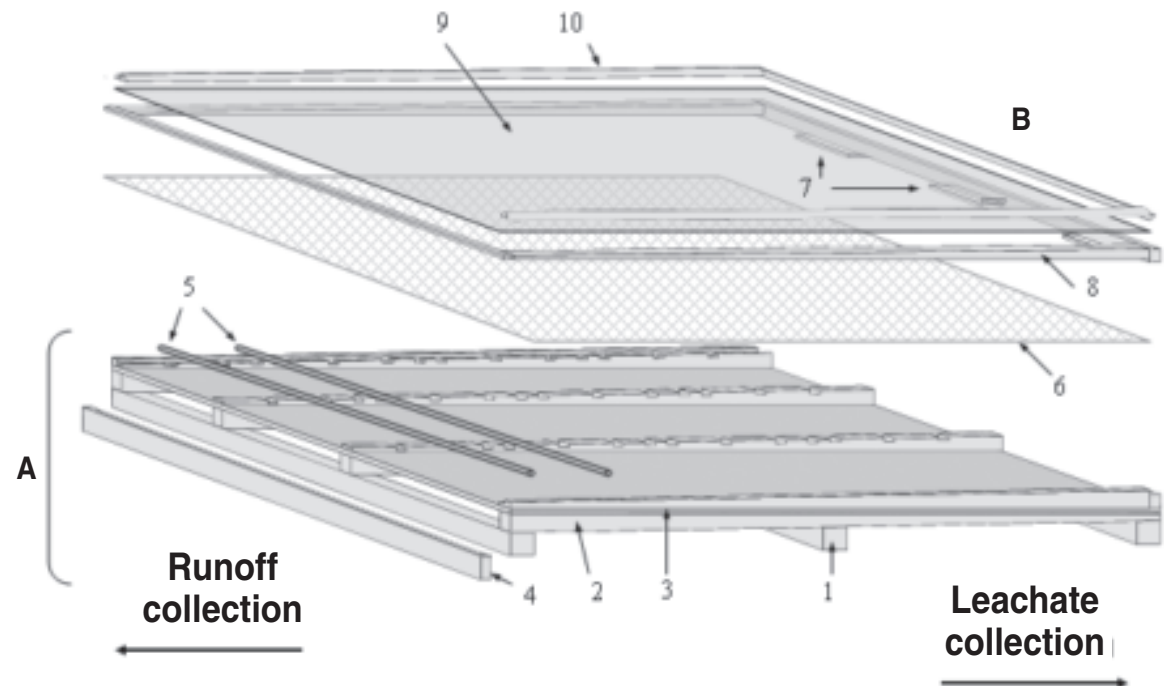

Fig. 1. Partial schematic of the platforms used to collect both irrigation runoff and leachate: (1) three $4 \times 4$-inch-thick $\times 4$-ft-long supports; (2) four $2 \times 4$-inchthick $\times 8$-ft-long joists each cut in half lengthwise at a $2 \%$ slope; (3) one $4 \times 8$-ft sheet of 3/4-inch-thick plywood; (4) one $2 \times 4$-inch-thick $\times 4$-ft-long end-piece; (5) 16 stainless steel bars (1/2 inch o.d. $\times 47$ inches long); (6) four plastic grating panels; (7) support blocks for grating; (8) four framing pieces cut to $1.5 \%$ slope $(2 \times 4$-inch-thick $\times 8$-ft-long lumber $)$ or $11 \%$ slope $(2 \times 12$-inch-thick $\times$ 8-ft-long lumber) and filled with underlay treatments; (9) woven, polypropylene groundcloth; (10) pairs of "quarter round" molding. Pond liner (not shown) was placed underneath the steel rod supports to form troughs to collect and conduct leachate. Three layers of $1 / 8$-inch fiberglass mesh (not shown) were placed over grating before adding underlay substrates $(1$ inch $=2.54 \mathrm{~cm} ; 1 \mathrm{ft}=0.3048 \mathrm{~m})$.

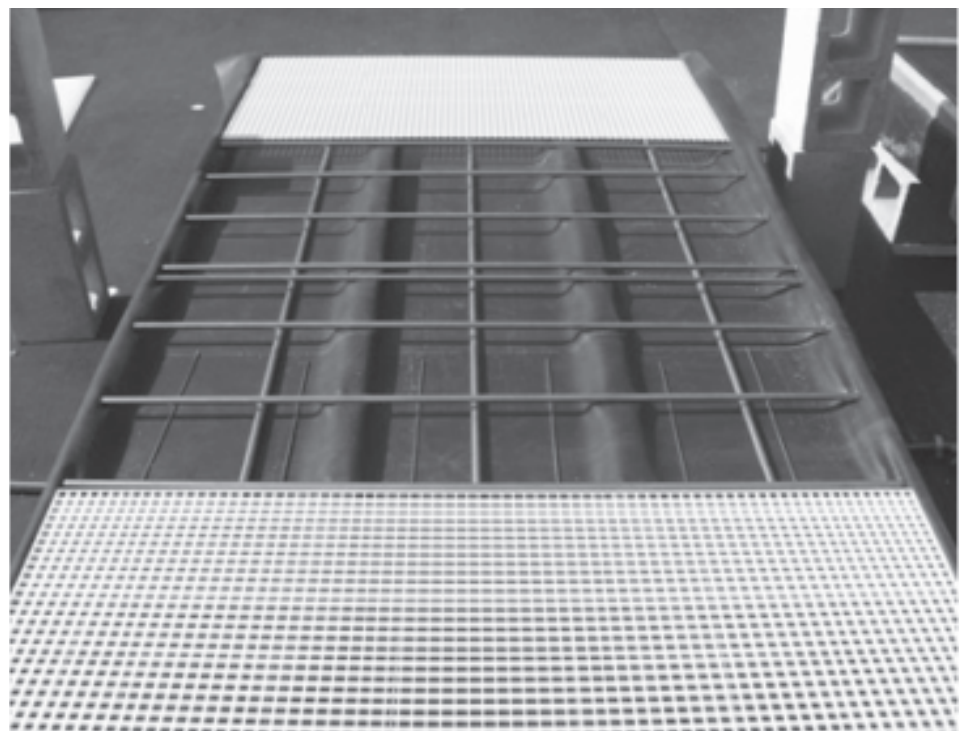

Fig. 2. This photo shows the base of the runoff platform during construction and reveals the steel bars, which were required to support the weight of the underlay materials.

duction beds. Also, preliminary tests indicated that RP for an intermediate slope of $5 \%$ slope was similar to RP observed for the $1.5 \%$ slope. Framework "B" was constructed from lumber either 2 inches wide $\times 4$ inches tall $\times$ $8 \mathrm{ft}$ long (1.5\% slope platform) or 2 inches wide $\times 12$ inches tall $\times 8 \mathrm{ft}$ long lumber (11\% slope platform) to obtain the desired final slope. Two 8-ft-long sections were cut at the desired slope with a height at the lower end of $1 / 2$ inch; the 4-ft-long end-piece was cut at a uniform height of 2 inches ( $1.5 \%$ slope) or 11 inches (11\% slope). The bottom of frame " $\mathrm{B}$ " was level while the slope of the top of the frame ran opposite to the slope of the plywood 
sheet in assembly "A." To help support the plastic grating at the open end of assembly "A," pieces of $1 / 2$-inch acrylic block were attached to the lower surface of the end-piece, so that they supported the outer edge of the grating panel between the joists. Once framework " $\mathrm{B}$ " was attached to "A," three layers of fiberglass mesh ( $1 / 8$ inch; not shown in Fig. 1) were placed over the grating of assembly "A" and stapled to the lower inside wall of framework "B" pieces. Three layers were used because this retained the finer underlay substrates tested while still exhibiting excellent drainage. The actual permeability of the three layers of screening was unknown and not determined. The entire upper framework " $\mathrm{B}$ " was filled with underlay substrate. Because the bottom of framework " $\mathrm{B}$ " was level to promote uniform downward drainage of leachate, the fill depth of underlay varied, being greatest at the high end of the platform and least at the lower end. A $4 \times 8$ - $\mathrm{ft}$ section of woven polypropylene groundcloth [weight $=102 \mathrm{~g} \cdot \mathrm{m}^{-2}$, thickness $=16 \mathrm{mil}$, water permeability (American Society for Testing and Materials D4491) $=611$ $\mathrm{L} \cdot \mathrm{min}^{-1} \cdot \mathrm{m}^{-2}$ (Green Line Style 3141 1; LINQ Industrial Fabrics, Summerville, S.C.)] was placed over the surface of the substrate and was stapled along the top edge of the frame. To channel the runoff water away from the lower edge of the platform, a section of pond liner was placed under the groundcloth before stapling the groundcloth to the platform frame. The unattached end of this liner "tail" was fed into a collection vessel described below. Pairs of "quarter-round" molding pieces were attached along the top edge of the frame to secure the edges of the groundcloth and to provide a defined irrigation collection area. Silicon caulk was applied under the inner molding piece to prevent water from running off the sides of the platform. The actual area of the platform receiving irrigation was $1.1 \mathrm{~m}$ wide $\times 2.4 \mathrm{~m}$ long or 2.7 $\mathrm{m}^{2}$ after accounting for the molding and a protective cover installed over the runoff edge of the platform.

Collection vessels were constructed from capped, 50-inch-long sections of 8-inch (o.d.) polyvinyl chloride (PVC) pipe (Fig. 3). A 2-inch-wide slit was cut along the top of the collector into which the pond liner "tail" could be placed. Each collection vessel was fitted with a drain valve fashioned from standard 3/4-inch PVC fittings and a 3/4-inch ball valve. The collection vessel capacity was $50 \mathrm{~L}$, which was sufficient to completely capture $0.9 \mathrm{~cm}$ of irrigation from the platform area. There were two collection vessels for each platform: one for surface runoff and one for leachate. Leachate and runoff were weighed to nearest 0.01 $\mathrm{kg}$ using a mobile balance.

EFFECT OF SLOPE AND UNDERLAY. Two platforms were constructed with either a $1.5 \%$ or $11 \%$ slope and placed inside of an irrigation zone $20 \mathrm{ft}$ wide $\times 20 \mathrm{ft}$ wide (Fig. 3). A duplicate pair of platforms was placed in an adjacent irrigation zone of the same dimensions so that there were two blocks (irrigation zones) and two treatments (slope) per block. Each zone was irrigated with four overhead sprinklers (model PGP No. 2 Nozzle; Hunter Industries, San Marcos, Calif.). Each sprinkler operated at a regulated pressure of $30 \mathrm{psi}$ with an application radius of $24 \mathrm{ft}$. The sprinkler pattern was adjusted to deliver uniformly water at $1.8 \mathrm{~cm} \cdot \mathrm{h}^{-1}$. We selected an irrigation cycle of 30 min, which resulted in a delivery of $0.9 \mathrm{~cm}$ of water per irrigation event. Irrigation uniformity for each irrigation zone was evaluated by collecting irrigation water in sixteen $8.5-\mathrm{cm}$ (i.d.) cups placed equidistantly on the two platforms. Christiansen's uniformity coefficient (Haman et al., 1997) for each irrigation zone was $95 \%$ or greater for each of three 30-min irrigation events evaluated.

Five different underlay treatments were evaluated: 1) no underlay, 2) coarse sand, 3) $50 \%$ coarse sand and $50 \%$ no underlay (CS50), 4) gravel, and 5 ) native sandy soil. Due to the difficulty in platform construction, the underlay treatments were evaluated one at a time and as such were separate experiments. The no underlay treatment was included to evaluate runoff that might occur in situations with poor groundcloth contact with underlay. The particle size distribution of the coarse sand was $1 \%>4 \mathrm{~mm}, 18 \% 1.4-4$ $\mathrm{mm}, 65 \% 0.5-1.4 \mathrm{~mm}$, and $17 \%<0.5$ $\mathrm{mm}$. This distribution corresponded to $84 \%$ coarse sand or coarser and $16 \%$ medium sand or finer. For the CS50 treatment, two $2-\mathrm{ft}$ horizontal swaths of sand were removed leaving three 16-inch-wide swaths of sand in contact with the groundcloth (one in the middle and one on either end of the platform). This treatment was designed to evaluate the influence of partial contact of groundcloth with the underlay such that might occur when groundcloth is placed over an uneven surface. The gravel (No. 89; Florida Rock Industries, Gainesville, Fla.) consisted of angular pebble gravel $6.4 \mathrm{~mm}$ to $9.5 \mathrm{~mm}$ in diameter. The native soil was taken from the Ap layer $(0-23 \mathrm{~cm})$ of a Millhopper sand (loamy, siliceous, hyperthermic, Grossarenic Paleudult). Milhopper sand is classified in Hydrologic Group A exhibiting high infiltration rate when wet and high permeability of $15-5 \mathrm{l} \mathrm{cm} \cdot \mathrm{h}^{-1}$ (SCS, 1985). Particle-size analysis indicated it contained by weight $92 \%$

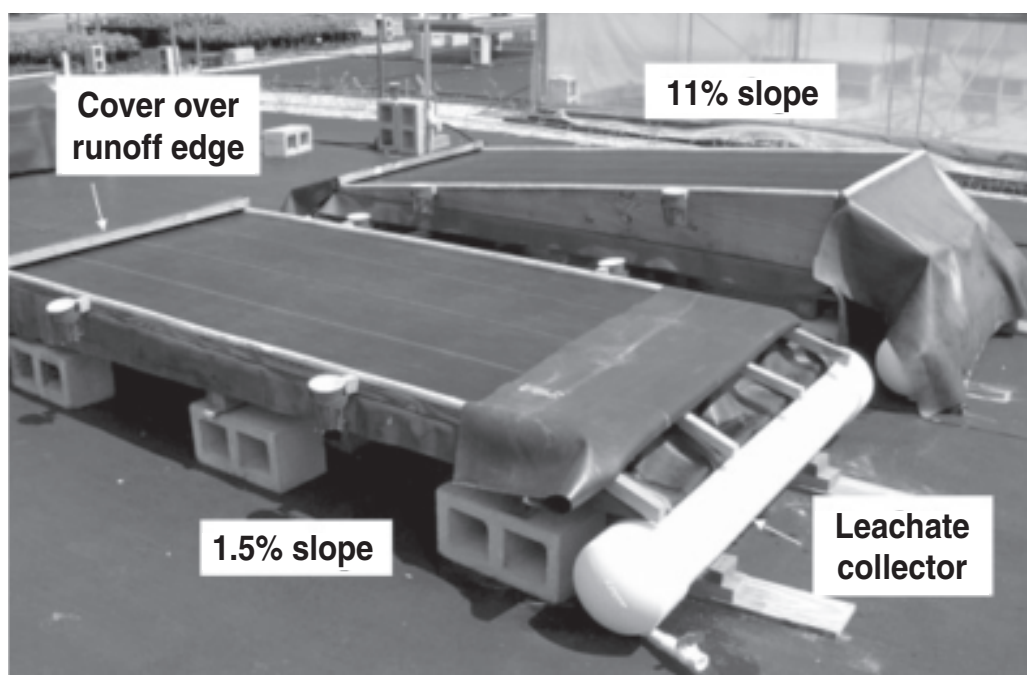

Fig. 3. Finished runoff platforms with $1.5 \%$ and $11 \%$ slopes used to collect runoff and leachate from single irrigation events. The leachate collection vessel of the $1.5 \%$ slope platform is shown to reveal that leachate was collected in the opposite direction of runoff. 
sand ( $4 \%$ coarse, $35 \%$ medium, $47 \%$ fine, and $6 \%$ very fine), $4 \%$ silt, and $4 \%$ clay (SCS, 1985). The soil was sieved (1/4-inch mesh) to remove any large roots, stones or other debris. The soil was watered periodically and packed during the filling of the platform. The resultant bulk density was $1.7 \mathrm{~g} \cdot \mathrm{cm}^{-3}$, which was denser than $1.5 \mathrm{~g} \cdot \mathrm{cm}^{-3}$ for the Ap horizon but similar to the 1.5 $-1.8 \mathrm{~g} \mathrm{~cm}^{-3}$ densities reported for lower $\mathrm{B}$ horizons of the Millhopper sand (SCS, 1985).

Runoff and leachate water were measured after each of five irrigation events per underlay treatment. For each irrigation event, water was applied at $0500 \mathrm{HR}$ and again at 0630 HR. Leachate and runoff water were collected from the second irrigation only: the first irrigation was applied to moisten the underlay to provide a standard antecedent moisture condition in the underlay and groundcloth. No tests were conducted on days with interfering rain or wind. Leachate volume (LV) and runoff volume (RV) were measured at $0800 \mathrm{HR}, \mathrm{l} \mathrm{h}$ after irrigation ceased. Total volume (TV) was calculated as the sum of leachate and runoff volumes. Runoff percentage was calculated as: $\mathrm{RV} \times 100 \% / \mathrm{TV}$. Percentages are reported because of the low values observed. An analysis of variance by PROC GLM (SAS Institute, Inc., Cary, N.C.) was conducted separately for each underlay treatment. There were two platforms (blocks) and two slope treatments evaluated per underlay. Ninety-five percent confidence intervals for runoff percentage means $(n=10)$ were calculated for each slope treatment by the LSMEANS/CL option in PROC GLM procedure.

\section{Results and discussion}

We found the platforms to perform as designed provided we paid attention to a few details. The creation of a smooth and uniform transition between the groundcloth and underlay at the lower platform edge was important to ensure water movement was not affected as water left the platform. Uniform contact between groundcloth and substrate across the entire platform was best obtained by forming a very slight convex shape across the horizontal dimension of the platform. This was accomplished by using a slightly bowed skreeting board when filling the platform with the underlay substrate. We exposed the groundcloth to sunlight, periodic rainfall, and daily irrigation for 2-3 weeks to remove the hydrophobic film that is commonly present on the surface of new groundcloth. Geotextiles are typically washed with water prior to permittivity testing (Carroll, 1987).

To achieve consistent results, we standardized the antecedent moisture by creating saturated conditions in both the underlay substrate and the groundcloth. Underlay substrates and groundcloth lose water via evaporation during the day resulting in variable antecedent moisture levels. We found the most practical way to achieve uniformity was to irrigate the platforms 1.5 $\mathrm{h}$ before an irrigation test. This time interval allowed for platforms to drain and provided sufficient time to prepare the platforms for the test run.

Runoff volume increased as platform slope increased from $1.5 \%$ to $11 \%$ (Table 1 ). An increase in RV at the $11 \%$ slope $(P<0.05)$ was observed for each of the underlay treatments . Total volume for all underlay treatments except gravel was not different due to slope. For gravel underlay, approximately $5 \%$ less TV was collected on the $11 \%$-sloped platform than on the 1.5\%-sloped platform. Particularly for this case, RP values should provide a more accurate means of comparing the effects of slope and underlay on runoff partitioning than $\mathrm{RV}$ or $\mathrm{LV}$ alone.

Runoff percentage values are given because they provide a direct relationship between runoff, leachate and total volume. All underlay treatments resulted in RP less than $0.7 \%$ at the $1.5 \%$ slope (Table 2). Based upon confidence intervals, RP means at the $1.5 \%$ slope were not significantly greater than $0 \%$ for any of the underlay treatments. For each underlay, RP was higher $(P<0.05)$ at the $11 \%$ slope than at the $1.5 \%$ slope. A two to three-fold higher RP was observed for gravel and native soil than for coarse sand underlay treatments at the $11 \%$ slope. Based upon confidence intervals, RP was similar for coarse sand and CS50 and for gravel and native soil. Regardless of the underlay, RP at the $11 \%$ slope was $3.1 \%$ or less. In the absence of an underlay substrate, RP at the $11 \%$ slope increased to $15.7 \%$.

Results indicated that underlay treatments had a greater effect on RP at the $11 \%$ slope than at the $1.5 \%$ slope. Based upon confidence intervals, RP for gravel underlay was not greater than the RP for other underlay treatments when tested at the $1.5 \%$ slope. At the $11 \%$ slope, however, RP was 2.2 -fold higher for gravel than for coarse sand ( 2.5 vs. $1.1 \%)$. Evidently, there is sufficient contact between underlay and groundcloth for rapid water infiltration at the $1.5 \%$ slope but less so at the $11 \%$ slope when water is moving more rapidly across the surface. Similarly, while irrigation water rapidly penetrated the native sandy soil underlay at the $1.5 \%$ slope, penetration at the $11 \%$ slope was reduced resulting in a RP of 3.1\%. Millhopper sand, which is typical of the sandy soils of central Florida, is classified as a permeable soil with rapid infiltration. We believe that sandy soils of the same hydrological classification would behave similarly. However, finer-textured soils or soils

Table 1. Influence of slope on irrigation runoff volume (RV), leachate volume (LV), and total volume (TV) collected from runoff platforms $\left(2.7 \mathrm{~m}^{2}\right)$ filled with selected underlay substrates and covered with woven polypropylene groundcloth. Platforms recieved $0.9 \mathrm{~cm}$ of overhead irrigation at the rate of $1.8 \mathrm{~cm} \cdot \mathrm{h}^{-1}$. Each underlay treatment was analyzed as a separate experiment $(\mathrm{n}=10)$.

\begin{tabular}{|c|c|c|c|c|c|c|c|c|c|c|c|c|c|c|c|}
\hline \multirow[b]{3}{*}{ Slope } & \multicolumn{15}{|c|}{ Underlay substrate treatment } \\
\hline & \multicolumn{3}{|c|}{ Coarse sand } & \multicolumn{3}{|c|}{$\mathrm{CS50}^{\mathrm{z}}$} & \multicolumn{3}{|c|}{ No underlay } & \multicolumn{3}{|c|}{ Gravel } & \multicolumn{3}{|c|}{ Native sandy soil } \\
\hline & RV & LV & TV & RV & LV & TV & RV & LV & TV & $\overline{\mathrm{RV}}$ & LV & TV & RV & LV & TV \\
\hline $11 \%$ & 0.27 & 24.24 & 24.50 & 0.16 & 24.92 & 25.08 & 3.65 & 19.75 & 23.39 & 0.57 & 22.22 & 22.79 & 0.78 & 23.77 & 24.55 \\
\hline Slope effect & * & NS & NS & * & Ns & NS & $* * *$ & $* * *$ & NS & $* *$ & $* *$ & * & $* * *$ & Ns & Ns \\
\hline
\end{tabular}

${ }^{2} 50 \%$ coarse sand and $50 \%$ no underlay (two 2 -ft horizontal swaths of sand removed).

ns, ${ }^{*},{ }^{* *},{ }^{* * *}$ Nonsignificant or significant at $P<0.05,0.01$, or 0.001 , respectively. 
Table 2. Effects of slope and underlay on runoff percentage for woven polyethylene groundcloth. Runoff platforms were irrigated with $0.9 \mathrm{~cm}$ of irrigation at $1.8 \mathrm{~cm} \cdot \mathrm{h}^{-1}$. LL and UL represent the lower and upper $95 \%$ confidence limits around the mean $(\mathrm{n}=10)$. Slope effect was significant $(P<0.05)$ for each underlay treatment.

\begin{tabular}{|c|c|c|c|c|c|c|c|c|c|c|}
\hline \multirow{3}{*}{$\begin{array}{l}\text { Underlay } \\
\text { substrate } \\
\text { treatment }\end{array}$} & \multicolumn{10}{|c|}{ Runoff percentage ${ }^{\mathrm{z}}$} \\
\hline & \multicolumn{5}{|c|}{ 1.5\% Slope } & \multicolumn{5}{|c|}{ 11\% Slope } \\
\hline & Mean & LL & $\mathrm{UL}$ & $\operatorname{Min}^{y}$ & Max $^{y}$ & Mean & $\mathrm{LL}$ & $\mathrm{UL}$ & Min & Max \\
\hline No underlay & 0.48 & -2.85 & 3.82 & 0.05 & 0.97 & 15.72 & 12.39 & 19.05 & 5.57 & 27.91 \\
\hline Coarse sand & 0.12 & -0.24 & 0.48 & 0.00 & 0.40 & 1.08 & 0.71 & 1.44 & 0.00 & 2.61 \\
\hline $\operatorname{CS} 50^{x}$ & 0.05 & -0.26 & 0.36 & 0.00 & 0.33 & 0.65 & 0.33 & 0.96 & 0.00 & 1.78 \\
\hline Gravel & 0.66 & -0.18 & 1.51 & 0.00 & 3.85 & 2.51 & 1.66 & 3.35 & 0.52 & 5.11 \\
\hline Native sandy soil & 0.09 & -0.63 & 0.81 & 0.00 & 0.67 & 3.13 & 2.41 & 3.85 & 0.98 & 5.83 \\
\hline
\end{tabular}

${ }^{2}$ Runoff percentage $=[$ runoff volume $\times 100 \% /($ runoff volume + leachate volume $)]$.

${ }^{y} \mathrm{Min}$ and max represent the minimum and maximum values observed for a single irrigation.

${ }^{\times} 50 \%$ coarse sand and $50 \%$ no underlay (two horizontal swaths of sand removed).

susceptible to compaction (e.g., Hydrological Class B-D) (SCS, 1985) may exhibit higher RP.

We have occasionally observed in container nurseries areas exhibiting poor infiltration of irrigation or rainfall through groundcloth and noted that this often occurred in places where there was poor contact between the groundcloth and the underlay. In the absence of an underlay, RP was $0.5 \%$ at the $1.5 \%$ slope but was $15.7 \%$ at the $11 \%$ slope. Without contact of an underlay substrate to draw water downward away from the overlying groundcloth, water was susceptible to running off the groundcloth surface at the $11 \%$ slope. The CS50 treatment was designed to test whether areas of poor contact of groundcloth with underlay would affect RP. Our results indicate that the water running off the area of the platform with no coarse sand quickly penetrated the groundcloth once it reached the area with coarse sand underlay, so that overall, the RP for CS50 was similar to that observed for coarse sand.

Results from this experiment provide insight on the relative influence of slope and underlay of plant nursery growing areas on irrigation runoff. Irrigation RP should be less than $1 \%$ of that intercepted provided the underlay is coarse-textured like the underlay substrates evaluated in our experiments and that subsurface drainage is unimpeded. Even at $11 \%$ slope, RP was no greater than $3 \%$. The exception to this was when no underlay was present at all. We believe that the presence of containers on the groundcloth surface may increase infiltration of irrigation water by slowing down water movement across the surface of the groundcloth and by increasing groundcloth contact with underlay in areas with poor contact. If this is true, actual RP would be less than reported herein.

While we acknowledge the inherent limitations in the direct application of results from small platform experiments to predicting irrigation runoff in actual field conditions, some useful information was gained. Results indicate that there will be little surface runoff of nutrients and other agrichemicals in container leachate following irrigation provided that underlay conditions similar to the ones used in our experiment exist in a nursery. The movement of irrigation water and associated agrichemicals into the underlay versus movement as surface runoff to a collection pond or other basin has major implications for the environmental fate of these pollutants. For example, P and many organic agrichemicals (e.g., pesticides, herbicides, growth regulators, etc.) can interact with the underlay and soil below to reduce or limit their potential effect on groundwater or other bodies of water in the watershed. On the other hand, very little surface runoff to a collection pond or water-retaining structure precludes the collection and reapplication of nitrogen and other nutrients associated with container leachate. Our results also indicate that the installation of coarse sand or gravel underlay at a site may not be warranted solely on the basis of reducing irrigation runoff, particularly if the native soil is sandy and the slope is low. We did not investigate irrigation runoff for poorly drained underlay substrates. Additional experimentation is needed to evaluate compacted underlay substrates or finer-textured soils exhibiting lower water infiltration and permeability characteristics. Experiments to determine runoff percentages from high-intensity rainstorm events would also be of interest for water managers.
The platforms used in this study could be used for these rainfall experiments as long as the collectors were modified to contain the potentially large quantities of runoff and leachate. Because the platforms were designed to support containers, these platforms could also be used to monitor leachate and runoff of fertilizers and agrichemicals during plant production.

\section{Literature cited}

Beasley, R.P. 1977. Erosion and sediment control guide. Iowa State Univ. Press, Ames.

Bilderback, T.E. 2001. Environmentally compatible container plant production practices. Acta Hort. 548:311-318.

Briggs, J.A., M.B. Riley, and T. Whitwell. 1998. Quantification and remediation of pesticides in runoff water from containerized plant production. J. Environ. Qual. 27:814-820.

Carroll, R.G., Jr. 1987. Hydraulic properties of geotextiles, p. 7-20 In: J.E. Fluet (ed.). Geotextile testing and the design engineer. Amer. Soc. Testing and Materials (ASTM) Spec. Tech. Publ. 952.

Cole, J.C., V.L. Stamback, and C. Gray. 1993. Design for a simulated nursery for water runoff research. HortScience 28(9):952-953.

Haith, D.A. and B. Andre. 2000. Curve number approach for estimating runoff from turf. J. Environ. Qual. 29:1548-1554.

Haman, D.Z., A.G. Smajstrla, and D.J Pitts. 1997. Uniformity of sprinkler and microirrigation systems for nurseries. Bul. 321. Florida Coop. Ext. Serv. Inst. Food Agr. Sci., Univ. of Florida, Gainesville.

Hillel, D. 1980. Fundamentals of soil physics. Academic Press, New York.

Parr, J.F. and A.R. Bertrand. 1960. Water infiltration into soils. Adv. Agron. 12:311-363.

Schwab, G.O., R.K. Frefert, K.K. Barnes, and T.W. Edminster. 1971. Elementary soil and water engineering. 2nd ed. Wiley, New York.

Soil Conservation Service. 1985. Soil survey of Alachua County, Florida. USDA-Soil Conservation Serv., Washington, D.C. 